\title{
Aesthetic Significance of Christian Redemption
}

\section{Shengda Guo}

Nanjing Normal University, China

DOI - http://doi.org/10.37502/IJSMR.2021.4713

\begin{abstract}
Redemption, as an important concept of monotheism, has not only different meanings in ancient Greece and Judaism, but also has many aesthetic meanings: the arousal of lofty desire, the inspiration to the courage of life, the importance of gratitude, the strong beliefs after finishing a long journey, the strengthening of sacred meaning in daily life through rituals etc. It could finally give mankind a bright future through thinking and pursuing these meanings. These aesthetic meanings have been expressed by various external forms (such as art, etc.) to guide people for a long time. In the modern history of China, with the continuous spread of Christianity in China, the concept of redemption and its related values have gradually been understood and recognized by Chinese people, and they also are introduced into the scope of daily life aesthetics and art appreciation, becoming a common term in people's life.
\end{abstract}

Keywords: Redemption, Freedom, Art, Aesthetics, Aesthetic significance.

\section{Introduction}

Religion stems from people's thinking about their own ultimate fate and related social practices. Some of the thinking are about doubts and fears to individual life's death, some include the exploration and anxiety about the uncertainty of human beings and the universe, and other are with the curiosity about certain specific objects (such as the sun, the moon, the mountains, and the grass, etc.), as well as longing and desire for certain superpowers. However, there is an important presupposition about all kinds of thinking and pursuit of human destiny, which is, how people can overcome their own limitations to reach what they desire. At this time, redemption is an important means or bridge. Redemption is an important religious concept, which is especially recorded in many monotheistic teachings.

\section{The concept of redemption}

Redemption, as an important concept of monotheism, has different sources of meaning. For example, the significance of its ancient Greek background lies in the historical reality of the time: during the ancient Greek period, frequent wars between city-states made the plunder 
of slaves as an important source of wealth growth. For the victors, it is no problem to gain more wealth by plundering and occupying the fortunes of the losers. But among the prisoners of war, some were leaders of their own city. They were not capable of doing simple labor tasks. The victors certainly realized this, and allowed these senior prisoners of war to be redeemed for greater benefits. The ransoms were obviously much higher than the gains from the exploitation of performing labors. This is the origin of ransom. For the Jews, redemption has more meanings. A person, who suffered from temporary poverty, would mortgage his own property. After having mortgaged everything, he chose to mortgage himself as a slave for paying off the debts. But the owner of this person cannot keep him as a slave all the time. The slave's closest relatives or friends, have the right to redeem him (when there exists one more redeemer, the priority of redemption is determined by the close relationship with the slaver). The right and possibility of redemption is of great significance. Firstly, it clarified the possibility of redemption, which is encouraging. Secondly, the cost of redemption is clarified. Besides, the significance of priority redemption is also very significant. Many relationships (such as family relationships, friendships, etc.) among people become more meaningful.

Therefore, there could be a premise: Why do you need to be redeemed? What are the prerequisites of redemption? In various versions of religious texts, the premise of redemption is that people put themselves into a state of non-freedom (for many reasons, they are passive, such as defeat) for various reasons (often for their own reasons). Although in such situation, people have not lost their desire and pursuit of freedom. More importantly, they have the possibility of regaining their freedom. Of course, redemption-related costs must be paid, in expressions of ransom, forced labor, or obedience and surrender to owners who possess and control their freedom. This is the meaning of redemption.

In different religions, there are different opinions about freedom loss. In Christianity, it is because people eat the fruits of the tree of the knowledge of good and evil. Generally speaking, it is because of selfishness and greed that people lose their freedom. In Buddhism, this loss of freedom becomes the result of immoral behaviors in social life. However, since man is a kind of pursuit of freedom and self-improvement, the inherent strength of this pursuit constitutes the basis and motivation of the beautiful behavior of human society. In this way, redemption becomes a necessary and realistic action for every individual who loses his freedom.

But how does redemption work? In Christianity, redemption could be carried out at the cost of the death of Christ Jesus (a far-reaching topic is that redemption is based on the death of Jesus because of human's original sin. Without Jesus' death, people's original sin cannot be forgiven by the creator or God, and therefore cannot directly seek the accomplishing of the road of redemption. Here also refers to the relationship of some right). This death is a great sacrifice, because such a sacrifice is for the redemption of the world, not only for Jesus Himself. Therefore, it is intended to indicate the road of redemption, that is, the road of faith (of course, for Christianity, the more important point is the resurrection of Jesus. This resurrection also 
builds Christian confidence and faith for the future). In this way, redemption is given a higher meaning at the religious level: it is not only an individual's self-redemption, but also has more social significance.

\section{The Aesthetic Significance of Redemption}

Due to this point, the aesthetic significance of redemption can be understood and fully embodied at multiple levels:

First of all, this redemption could arouse people's longing for and pursuit of lofty values, thus giving life a sacred meaning. Human life does not only include a simple material satisfaction, but also a pursuit of spiritual freedom. The more people are satisfied with material life, the more demand they have to raise the level of their spiritual world. Therefore, the pursuit of lofty sacred values has become an inevitable content of people's spiritual life. Redemption itself is not only a path to realize the lofty value, but also a concrete manifestation in real life. Different from the belief "sanctify secular spiritual life" in traditional Chinese culture, Christianity sanctified the creator or God as the absolute sprits or highest value in the real world. The creator or God overlooks the world with an absolute and lofty attitude, and cares the world. Redemption is one of the expressions. In this way, on this road of redemption, people can not only feel the existence of God, but also the meaning of its existence to themselves in their trivial lives. These beliefs are of great significance to the lives of society and individuals.

Secondly, sacrificing one's life for others who is in an unfree situation in exchange for redemption could stimulate people's supreme courage of life. Everyone's life is unique and valuable, but much more valuable is dedicating one's life for the sake of the world. Faced with any difficulties, dangers, or even danger to life, people could face forward and move forward. This bravery has an inner conviction: for the redemption of more people who are in an unfree situation (to regain freedom and a better life). For the great love, people go forward fearlessly, even killing themselves is also at their expense. In the age of peace, although we do not face such a life danger, but the courage to face any difficulties and difficulties is very important to everyone's life.

Besides, redemption would inevitably arouse people's gratitude. It is very understandable, because redemption means a corresponding payoff. For example, redemption in Christianity is based on Jesus' death. Everyone who has passed this road of redemption must be grateful. In fact, only with gratitude, it is possible to embark on the road of redemption. The two are positively related. There is not only the positive significance of ethics, but also people's great conviction for the pursuit of a better life.

In addition, redemption is a long-term and continuous process. People must be firm, persistent and unmoved by all kinds of temptations and perplexities before they could complete redemption and finally realize their original intention: to regain freedom. In this process, personal qualities and personalities have been improved, and wills have been exercised. This 
is not only the necessary presupposition for the completion of redemption, but also the harvest of the redemption process.

Moreover, redemption could not be obtained by just waiting. It's not an incoming food at all. Only those who through the power of faith, under the guidance of light, through the words and deeds of daily life, and through certain rituals could stand at the entrance of the road of redemption. Such rituals that are repeatedly performed in daily life (such as praying with full of reflection and gratitude, or hard work under a certain sacred belief), even if it is a specific trivial matter of life, under a sacred and beautiful belief, it is full of meaning, because it gives simple or boring life a sacred value. This means that although there are difficulties and hardships in the road of redemption, this is a happy journey.

Finally, the most important significance of redemption is to give people confidence in the value of life and future. Because of the road of redemption, the future is bright. The belief is absolute necessity in life. People would be in a dilemma (evil in the philosophical sense) due to their own greed, so they need their faith in the future more urgently, in order to pursue it persistently. Such a beacon of life is not only full of positive energy for the real life of individuals, but also full of positive significance for the development and progress of groups and society. For example, in the history of mankind, when a group or nation is in trouble such as natural disasters, wars, etc., there will always be someone who stands up and sets a clear and beautiful future and help build people's confidence in the future. With the man's help, people actively explore the path to this goal and personally take it into practice. They work hard to achieve this future goal. What the man achieves is that the value contains the great spirit of redemption: when he helps someone else realize personal goals, the great value of social development is realized as well. Actually, there are not only those great people in history, but also ordinary people who are worthy of respect and sacrificed for the sake of great social value, such as martyrs sacrificed in war, firefighters sacrificed for fire and disaster relief, etc. If we do not take sacrifice as the final condition and result of redemption, there are more people who dedicate to higher social value in daily life. This shows that redemption has obvious social value in daily life.

\section{Conclusion}

The meaning of redemption mentioned above not only reflects the individual's actual daily life, but also manifests itself in various concrete forms: the magnificent human architectural art that we admire and admire (various churches, temples, and many religiousrelated buildings). Etc.) Many of the great paintings, literary works, sculptures, music works, etc. that have been handed down to this day are showing the topic of redemption, guiding and guiding people on the road to redemption. If the value of human culture lies in the pursuit of true aesthetics and in pursuing and fulfilling people's desire to pursue a better life, then redemption is worthy of promotion in terms of its religious and cultural values. As human beings are constantly facing various survival crises such as plagues, various geological 
disasters, different climate disasters, environmental pollution and so on brought about by constantly mutating viruses, such a spirit of redemption has clear advocacy value and practical significance.

\section{References}

1) The Judgment: A Glimpse of Kafka's Aesthetics of Redemption Zhang Ruiqin Polpular Literature $2021(03)$

2) Society as the Subject of Redemption: The Relevance of the Social Gospel Dorrien Gary Tikkun Volume 24, Issue 6. 2021

3) On the Rational Basis of Revelation in Rosenzweig' s Star of Redemption Abraham Mounitz International Journal of PhilosophyVolume 9, Issue 2. 2021

4) Freedom, Salvation, Redemption: Theologies of Political Asylum Gearon Liam British Journal of Religious EducationVolume 43, Issue 1. 2021. PP 9-22

5) Redemption: Its Significance and Importance Yu Xiaofei Cui Xiaoxiong Translated by East China Normal University Press, May 2012

6) Exploration of Religious Significance by Hof Heinz, etc. Translated by Zhu Daiqiang, Sichuan People's Publishing House, January 2011

7) Stephen Hunt Religion and Social Daily Life Wang Xiaoxiu, Lin Hong Translation, Central Compilation and Translation Press, June 2010

8) Pan Zhichang's Draft on Life Aesthetics, Zhengzhou University Press October 2002 